\title{
Key Determinants of Willingness to Support Policy Measures on Recycling: A Case Study in Hong Kong
}

\section{Introduction}

Waste management strategies comprise key elements, such as waste reduction, reuse, and recycling. These elements help in the conservation of natural resources and the reduction of demands for landfill space (Environmental Protection Department, 2010). Although waste reduction and reuse at source are effective methods of minimizing waste (Tonglet, Phillips, \& Bates, 2004), these often require changes in consumption preferences and choices (Henry, Yongsheng, \& Jun, 2006), for example, bringing own bottles of water instead of purchasing bottled water, purchasing products in large quantities instead of individually packaged items, replacing individual components of electronic products instead of purchasing an entirely new one. Waste reduction and reuse behaviours that require changes in consumption habits and adjustment in lifestyles are more difficult to change than recycling behaviours (Mont \& Plepys, 2008; Vermeir \& Verbeke, 2006). Therefore, public authorities have emphasized the increase in household recycling levels (Tonglet, Phillips, \& Bates, 2004). Prior studies have shown that encouraging reduction and reuse behaviours requires different strategies and messages (Barr, Gilg, \& Ford, 2001; Ebreo \& Vining, 2001). Recycling is a method that requires intensive energy, specifically in collecting, transporting, and processing of recyclables and recycled items (Björklund \& Finnveden, 2005). Despite this, recycling behaviours have continued to receive considerable attention from researchers. This is because recycling behaviours are mainly influenced by situational factors, e.g. recycling facilities, which are more controllable by the public authorities; while waste reduction and reuse behaviours are more driven by people's own environmental values (Barr et al., 2001; Chen \& Tung, 2009).

The campaign to establish waste-separation facilities was introduced by the Hong Kong Government in 2005 to encourage and facilitate recycling (Environmental Protection Department, 2005). The government recognized the importance of mobilizing the community to support the campaign (Environmental Bureau, 2013). Government statistics showed that although population growth was merely $36 \%$ in the past three decades, the increase in municipal solid waste was nearly $80 \%$. In essence, Hong Kong residents have been producing wastes at an alarming rate. Various policy measures (e.g., waste charging, development of an EcoPark, community mobilization projects) have been proposed by the government to encourage and facilitate recycling and waste reduction (Environmental Bureau, 2013). 
The citizens of Hong Kong have become increasingly outspoken about their demands for democracy since the change of sovereignty in 1997 (W. Chan, 2007). On July 1, 2003, half a million Hong Kong residents took to the streets to protest against the HK SAR Government as a gesture of solidarity. This day was a defining moment for Hong Kong. Surprisingly, the bulk of demonstrators were professionals, civil servants, students, businessmen, young people, and families, in addition to the regular protesters from political parties or interest groups (W. Chan, 2007). Post-80s, which refers to the group of people born after 1980, became a buzzword in Hong Kong. The term supposedly describes the youth, who are driven to rash and radical extremes because of frustration over the diminishing opportunities for upward mobility and comparatively high unemployment rate (Sin \& Mok, 2010). A media sector regarded the Post-80s as an aggressive group of the youth movement, and public discussion has been spurred by the radical edge of recent protests (Hui, 2010; Phillips, 2014). The civil society in Hong Kong has experienced tremendous growth after the change of sovereignty. Hong Kong people are no longer content with having important decisions made for them by the government; thus, they demand participation in policymaking (E. Chan \& Chan, 2007). The people's growing sentiments to retain local roots are evident in their call for higher levels of participation, as well as in their concerns over the loss of the city's Hongkongness (A. Cheung, 2007).

Prior studies in the field of environmental psychology examined the key factors influencing recycling behaviour (Sidique, Lupi, \& Joshi, 2010; Tonglet, Phillips, \& Read, 2004; Wan, Shen, \& Yu, 2014). Majority of these studies focused on direct behaviours, specifically environmental action (Kollmuss \& Agyeman, 2002). Indirect recycling behaviours, such as voting for a politician and supporting government policy, are rarely studied (Courtenay-Hall \& Rogers, 2002). Rauwald and Moore (2002) suggested that gaining policy support from the citizens is essential to the efforts of governments to institute environmental policies. The limited studies on policy support focused on a particular predictor variable, i.e. a variable considered to influence or predict an outcome variable (Field, Miles, \& Field, 2012). For example, Rauwald and Moore (2002) examined how environmental attitudes influence policy support. In addition, these studies simplistically considered policy support as a single construct (e.g., Daneshvary, Daneshvary, and Schwer (1998)). No comprehensive research that extensively examines the psychological determinants that influence policy support on recycling policy or considers the difference among policy measures has been published.

Policy makers should understand the key psychological determinants of policy support to gain public recognition in policy formulation and implementation, particularly in Hong Kong, which is a land-hungry and compact city (Tang, Wong, \& Lee, 2007). Such understanding is 
particularly important to waste management. Hong Kong heavily relies on landfills that will reach their full capacities by the end of the 2010s. The government aims to reduce landfilling rate from $52 \%$ to $22 \%$ through incineration and recycling in ten years (Environmental Bureau, 2013). Aligned with this aim, this study examines the key psychological determinants influencing policy support for various policy tools on recycling, and intends to draw policy implications that could enhance the support of citizen for recycling policies.

The rest of the paper is organized as follows. Section 2 presents a summary of literature on policy support and key psychological determinants. Section 3 discusses the proposed research model and hypotheses. Section 4 describes the research methodology. Data analyses and research findings are presented in Sections 5 and 6, respectively. Discussion on the research results is presented in Section 7, and conclusions are provided in Section 8.

\section{Literature Review}

\subsection{Policy Support: A Pro-Environmental Behaviour}

Environmental behaviour is defined as any behaviour that "changes the availability of materials or energy from the environment or alters the structure and dynamics of ecosystems or the biosphere itself' (p. 408) (Stern, 2000). This definition includes both environmentally friendly and damaging behaviours. Compared with pro-environmental behaviour, which refers to a behaviour "that harms the environment as little as possible, or even benefits the environment" (p. 309), environmental behaviour is a broader term (Steg \& Vlek, 2009). Given that most environmental problems are rooted in human behaviours (Vlek \& Steg, 2007), a considerable number of studies have been conducted to identify factors that affect various types of pro-environmental behaviours, and determine the processes that influence these behaviours. These studies focused on energy saving (Poortinga, Steg, \& Vlek, 2004), public transportation utility (Heath \& Gifford, 2002), recycling (Tonglet, Phillips, \& Bates, 2004), and green product purchase (R. Y. Chan, 2001), among others. Although studies have focused on a range of behaviours, such as that of Dolnicar and Grün (2009),which covered recycling, energy saving, and green purchases, among others, different behaviours motivated by different psychological and situational factors (McKenzie-Mohr, Nemiroff, Beers, \& Desmarais, 1995) and different types of pro-environmental behaviours have not been correlated with each other (Thøgersen \& Ölander, 2003), for example, an individual who performs recycling behaviour does not necessarily purchase green products.

Kollmuss and Agyeman (2002) suggested that pro-environmental behaviour can be categorized as direct and indirect. Examples of indirect behaviours are supporting 
government policies, voting for favorable politicians, or signing petitions; whereas direct behaviours refer to the performance of pro-environmental actions. Stern (2000) similarly suggested that supporting or accepting policy is considered as a non-activist behaviour that indirectly influences the environment through its impact on public policies. This is an important class of behaviour because policies can change the behaviours of people and organizations (Schneider \& Ingram, 1990). Previous studies on pro-environmental behaviours in the field of environmental psychology mostly focused on the frequency with which people engage in certain behaviours, such as recycling, energy use, and so on (Steg \& Vlek, 2009). As a form of indirect behaviour, policy support from citizens is vital because it can enhance political feasibility and effectiveness of implementation (Rauwald \& Moore, 2002). In addition, studies on policy support simplistically considered policy support as a single psychological construct (Daneshvary et al., 1998; Rauwald \& Moore, 2002; Tobler, Visschers, $\&$ Siegrist, 2012; Wan et al., 2014). However, different policy tools can exert different levels of influence on citizens (Elmore, 1987); thus, these tools may gain different levels of support.

Steg and Vlek (2009) stated that two strategies can be used to intervene in the pro-environmental behaviour of the individual: (i) informational strategies that generally aim to enhance knowledge and awareness of the individual and (ii) structural strategies that intend to change contextual factors including the costs and benefits of behavioral alternatives. Wan and Shen (2013) listed three common policy tools used by policy makers in promoting pro-environmental behaviours based on the tools categorized by Elmore (1987).

- Mandates - Rules regulating behaviour in which policy makers formulate a package of generally acceptable rules, punishments, and enforcement

- Inducements - Provision of encouragements to stimulate behaviour

- Capacity-building - Transference of money for investing in future materials, intellectual, or human resources

The current recycling policy measures in Hong Kong includes the proposed waste charging, the plastic bag levy, and the construction waste charging (Environmental Bureau, 2013; Environmental Protection Department, 2010). However, these fees serve as disincentives (i.e., negative inducement) for waste production but not as incentives for recycling. The government has also earmarked a fund to improve publicity and public education, as well as to develop an EcoPark for the local recycling industry (Environmental Protection Department, 2010). The fund acts as an investment in the future development of the intellectual knowledge of the individual and industry development, which can be considered as a capacity-building initiative. Thus, the Hong Kong Government has been implementing inducement and capacity building as policy measures to encourage and facilitate the industry. 


\subsection{Psychological factors influencing pro-environmental behaviour}

Five factors, namely, attitudes, social/external influences, perceived benefits, past behaviour, and perceived policy effectiveness generally determine pro-environmental behaviours (Bamberg \& Möser, 2007; Monroe, 2003; Steg \& Vlek, 2009; Stern, 2000; Wan et al., 2014).

Attitude is defined as a function of an individual's beliefs towards an object, and a subjective evaluation of that object (Fishbein \& Ajzen, 1975). Miller (1956) suggested that although individuals hold numerous beliefs (an internal cognitive content), they can only invest efforts in attending to a limited number of beliefs. Attitude is a fairly stable evaluative disposition through which individuals behave positively or negatively towards an object. In the studies of pro-environmental behaviour, attitudes can be divided into general environmental attitudes and specific attitudes. General environmental attitude refers to a personal evaluation of environmental issues (Fransson \& Gärling, 1999). The New Environmental Paradigm Scale (NEP) developed by (Dunlap \& Van Liere, 1978) is a popular measurement scale for general environmental attitudes, which reflects individual beliefs on the relationship between humans and the natural environment. A review by Hawcroft and Milfont (2010) included a search for relevant articles that applied NEP, which resulted in the identification of more than 300 articles. Specific attitudes, as defined by Fishbein and Ajzen (1975), refer to a person's subjective evaluation towards a specific behaviour or object, which can be exemplified by specific attitudes towards recycling that refer to whether an individual positively or negatively assess the performance of recycling behaviours. Research on the relationship between general environmental attitudes and pro-environmental behaviours has produced mixed results (Schultz \& Oskamp, 1996), whereas those that studied specific attitudes have demonstrated that these attitudes are powerful predictors of behaviour (Balderjahn, 1988).

Social influences are standards that guide the behaviours of individuals and are shared among members of a group or society (Cialdini \& Trost, 1998). These standards and rules serve as cues that help people to know how they are expected to behave, and that adherence to social influences can gain social approval (Cialdini \& Goldstein, 2004). Abrahamse and Steg (2013) suggested that the use of social influences, learning, and comparison are effective in encouraging pro-environmental behaviours. Social influence can be narrowly defined as individual concerns on the perception of significant others, including family members and close friends (Tonglet, Phillips, \& Read, 2004), which can be considered as influences from a wide range of external sources, such as the media and other interest groups. Kingdon (1995) suggested that explanations on agenda prominence are a part of the political stream. Political events flow along according to their own dynamics and rules. Media and the visible 
participants have played important roles in directing the flow of the political stream. K. Chan (1998) argued that mass media is a major source of social influence. Mass media is pivotal to the political environment because it brings the issue to the spotlight. The pioneering study of McCombs and Shaw (1972) introduced the role of the media in the 1968 presidential campaign in Chapel Hill, North Carolina. Results showed the strong correlation between the rate at which the media covers a story and the extent that people regard such story as important. In the context of recycling, interest groups are one of the most important visible participants in recycling, through which conservationists have advocated environmental conservation for a long time. Fielding, McDonald, and Louis (2008) suggested that environmental groups influence individual engagement in pro-environmental behaviours.

Ajzen (1991) defined attitudes as comprising instrumental (knowledge) and experiential (feeling) components. Tonglet, Phillips, and Read (2004) argued that the attitude measured in previous studies focused on individual feelings, one of which was whether a behaviour is good or rewarding. However, minimal attention has been paid to instrumental components, which are vital in assessing the perceived benefits of recycling behaviours (Tonglet, Phillips, \& Bates, 2004; Wan et al., 2014). Davies, Foxall, and Pallister (2002) suggested that perceived benefits refer to the awareness of behavioral outcomes; a higher awareness level of desirable outcomes of recycling behaviours, such as environmental protection and natural resource preservation, increases the intention to perform recycling. Stern (1992) articulated that pro-environmental behaviours are influenced by knowledge on perceived costs and benefits.

Past behaviour refers to a past involvement in certain behaviours. Barr (2007) explained that past behaviour causes behavioral snowball effect (p. 439), which implies that an individual who adheres to a particular behaviour will be more willing to perform other behaviours. Past behaviour may influence future behaviour in two ways (Ouellette \& Wood, 1998). First, past behaviour influences future behaviour through habit formation (e.g., washing hands after using the toilet); thus, behaviour repetition is independent of conscious intention (Knussen, Yule, MacKenzie, \& Wells, 2004). Second, responses tend to be semiautomatic particularly for complex behaviours (Carrus, Passafaro, \& Bonnes, 2008; Ouellette \& Wood, 1998). Recycling behaviour is a complex behaviour that requires individuals to sort, store, and take recyclables to collection points. Each step requires a conscious and rational decision marking, in which past behaviour continue to influence intentions to perform specific behaviours (Carrus et al., 2008).

Policy measures can change mindsets and behaviours (Vedung, Bemelmans-Videc, \& Rist, 1998). Perceived policy effectiveness refers to the beliefs of stakeholders on the capability of 
public policies to achieve their objectives (Lubell, 2003); public policies that are perceived as effective are means through which political support and resources could be gained. Schneider and Ingram (1990) suggested that effective policy measures serve as motivational devices in changing behaviours. In a study on recycling behaviour by Wan et al. (2014), perceived policy effectiveness is defined as perception of a specific policy measure, which refers to people's feelings on how well the public authorities provide effective and adequate policies. The effectiveness and acceptability of policy measures in different fields, such as transportation (Jakobsson, Fujii, \& Gärling, 2000), energy conservation (Steg, Dreijerink, \& Abrahamse, 2005), and climate change (Tobler et al., 2012) have been examined. These studies emphasized the understanding of perceived effectiveness and acceptability of policy measures to gain public support and to formulate effective strategies that encourage desirable behaviours.

\section{Research Model and Hypotheses}

\subsection{Policy Support}

Kollmuss and Agyeman (2002) suggested that indirect behaviours (e.g., supporting government policies or voting for favorable politicians) are a form of pro-environmental behaviour. In Hong Kong, the government mainly used policy tools of inducement and capacity building as demonstrated by the introduction of waste charging and the allocation of funds for public education and the development of the local recycling industry (Environmental Protection Department, 2010). Therefore, this study defines policy support as two dependent variables based on the policy tools used, namely, support for inducement and capacity building.

Attitudes have been proven as a significant predictor that influences both direct and indirect pro-environmental behaviours (Rauwald \& Moore, 2002; Sidique et al., 2010; Tonglet, Phillips, \& Read, 2004). Compared with general environmental attitudes, specific attitudes are more powerful predictors of behaviours (Balderjahn, 1988; Do Valle, Rebelo, Reis, \& Menezes, 2005). Therefore, this study applies recycling-specific attitudes rather than general environmental attitudes. The following hypotheses are proposed:

\section{Hypothesis 1 (H1)}

If an individual has a more positive attitude towards recycling, he / she will be more likely to support inducement policy measures. 
Hypothesis 2 (H2)

If an individual has a more positive attitude towards recycling, he / she will be more likely to support capacity-building policy measures.

External influences including those of peers, media, and pressure groups are significant factors that impact pro-environmental behaviours (K. Chan, 1998; Cialdini \& Goldstein, 2004; Fielding et al., 2008). In the context of recycling behaviour, if an individual perceives that others are engaging in recycling or socially acceptable behaviours, he/she tends to engage in the same behaviour (Barr, 2007; Sidique et al., 2010; Tonglet, Phillips, \& Read, 2004). Thus, the current study proposes the following additional hypotheses:

Hypothesis 3 (H3)

If an individual perceives an external influence supporting recycling behaviour, he/she will be more likely to support inducement policy measures.

Hypothesis 4 (H4)

If an individual perceives an external influence supporting recycling behaviour, he/she will be more likely to support capacity-building policy measures.

Stern (1992) argued that pro-environmental behaviours are influenced by knowledge on perceived costs and benefits. Recycling consequences are often included as a predictor variable in recycling behaviour studies (e.g., Tonglet et al., 2004; Oom Do Valle et al., 2005). Davies et al. (2002) explained that higher awareness levels on the desirable outcomes of certain behaviours increase the intention to recycle. In the study by Tobler et al. (2012), perceived benefits are proven as a significant factor influencing policy support in the context of climate change. To conclude, we believe that perceived benefits of recycling is a possible factor influencing policy support for recycling. Thus, the following hypotheses are proposed:

Hypothesis 5 (H5)

If an individual perceives a higher level of recycling benefits, he/she will be more likely to support inducement policy measures.

Hypothesis 6 (H6)

If an individual perceives a higher level of recycling benefits, he/she will be more likely to support capacity-building policy measures. 
Empirical support for the impact of past behaviours on pro-environmental behaviour persists, including those provided by the study of S. F. Cheung, Chan, and Wong (1999), which identified the strong influence of paper recycling on the frequency of past behaviours. Prior recycling studies suggested that past recycling behaviour should be included in considering future recycling behaviour (Boldero, 1995; Knussen et al., 2004). Daneshvary et al. (1998) conducted a study on curbside textile-recycling in which current waste-recycling behaviour is a significant factor that influences the support for a curbside textile-recycling policy. The behavioral snowball effect proposed by Barr (2007) articulates that an individual performing a behaviour is more willing to perform the same behaviour in the future. Therefore, the following hypotheses are formulated:

\section{Hypothesis 7 (H7)}

If an individual has more past recycling behaviours, he/she will be more likely to support inducement policy measures.

\section{Hypothesis 8 (H8)}

If an individual has more past recycling behaviours, he/she will be more likely to support capacity-building policy measures.

Policy measures serve as motivational devices in changing behaviours (Schneider \& Ingram, 1990). Steg and Vlek (2009) argued that effective policy measures increase the attractiveness of pro-environmental behaviours. Wan et al. (2014) proved the relationship between perceived policy effectiveness and recycling behaviour. Given that a policy measure serves as a motivational device, then the perception of a stronger and more effective motivation enhances the intention to perform a certain behaviour. This observation implies that if a policy measure is perceived as effective, citizens tend to support such policy. If a government is effective in its governance, the people will support it. Hence, the following hypotheses are proposed:

\section{Hypothesis 9 (H9)}

If an individual has higher perception of policy effectiveness for recycling, he/she will be more likely to support inducement policy measures.

\section{Hypothesis 10 (H10)}

If an individual has higher perception of policy effectiveness for recycling, he/she will be more likely to support capacity-building policy measures. 
Drawing upon the aforementioned literature, a conceptual framework is formulated (Figure 1).

\section{Questionnaire Design and Data Collection}

The current study conducted a street survey. The questionnaire was composed based on the recycling literature. The questionnaire items are shown in Appendix A, and its details are as follows:

- The questionnaire included items on the five major independent variables: attitude, external influences, perceived benefits, past behaviour, and perceived policy effectiveness. The indicators of these variables were based on Sidique et al. (2010), Tonglet, Phillips, and Read (2004), and Wan et al. (2014).

- The indicators (questionnaire items) for the two constructs on policy support were based on the Environmental Protection Department (2010), from which the current and proposed policy measures in Hong Kong were drawn from.

- $\quad$ The survey used a seven-point Likert scale $(1=$ strongly disagree, $7=$ strongly agree $)$ to measure the five major independent variables and the two dependent variables (support for inducement and support for capacity-building policy measure) of the proposed model.

- The questionnaire consisted of questions, which sought to obtain demographic information, such as age, gender, education level, and monthly income.

A pilot test was conducted to improve internal validity. Twenty questionnaires were randomly distributed. Results were analyzed and utilized to improve the questionnaire and formulate the final version.

Belton, Crowe, Matthews, and Scott (1994) suggested that conducting a recycling survey in busy sites can cover a large part of the local population and both recyclers and non-recyclers. Therefore, the street survey was conducted in three major areas in Hong Kong and was carried out in six sites in these areas.

- Four shopping malls were selected based on the study of the tenant mix of shopping malls by Yiu and Xu (2012). These malls are easily accessible through public transportation.

- Two railway stations were included - one is located in a residential area with the highest population in Hong Kong (Census and Statistics Department, 2011), and the other, which is located in a commercial area, is regarded as one of the busiest stations (Information Services Department, 2012).

Following the street survey by González-Torre and Adenso-Díaz (2005), respondents were 
randomly chosen. Conducting surveys in selected sites is considered as stratified sampling, which allows examination of responses across a range of geographical locations and settings (Bator, Bryan, \& Schultz, 2010). The survey obtained 246 responses. Table 1 lists the profile details of the respondents.

\section{Data Analysis}

Structural equation modeling (SEM) measures latent, unobserved concepts based on multiple observed indicators (Chin, 1998a; Jöreskog \& Sörbom, 1989). Two major statistical approaches in estimating structural equation models include the covariance- and variance-based partial least squares (PLS) approaches (Hair, Ringle, \& Sarstedt, 2011). Compared with covariance-based SEM, PLS is more suitable for theory development and is not sensitive to small sample sizes (Hair et al., 2011; Jöreskog \& Wold, 1982; Lu, Kwan, Thomas, \& Cedzynski, 2011; Reinartz, Haenlein, \& Henseler, 2009). This study aims to examine the key determinants of policy support for recycling and the sample size is relatively small; thus, PLS was deemed appropriate (Henseler, Ringle, \& Sinkovics, 2009). The statistical software application SmartPLS 2.0 (Ringle, Wende, \& Will, 2005) for PLS-based path modeling was applied to measure the causal model.

The PLS analysis (Chin, 1998b) was accomplished in two steps. First, the PLS measurement model was evaluated by examining the convergent and discriminant validity, as well as the composite reliability of the indicators. The convergent validity and composite reliability tested the relationships among indicators within the same constructs, that is, questionnaire items (indicators) measuring the same variable (construct) should be highly correlated with each other. Measurement scales were evaluated based on the following criteria (Chin, 1998b; Fornell \& Larcker, 1981):

(i) All indicator factor loadings should be significant and exceed 0.5 .

(ii) Composite reliability should exceed 0.7 .

(iii) Average variance extracted (AVE) by each construct should exceed 0.5 .

Furthermore, the discriminant validity of indicators tested whether indicators within different constructs are unrelated (Campbell \& Fiske, 1959), that is, questionnaire items (indicators) measuring different variables (constructs), such as attitude and external influences, should be uncorrelated. A rule for assessing discriminant validity requires that the square root of the AVE should be larger than the correlations between the construct and any other factor in the model (Chin, 1998b; Fornell \& Larcker, 1981). 
In the second step of the PLS analysis, the structural model was assessed to confirm whether the hypotheses specified by the proposed model were statistically significant with the available data. The statistical significance of the hypotheses were determined by running the model using a bootstrap resampling routine with the cases (survey responses collected) and 1,000 sub-samples. In the bootstrapping, each of the sub-samples was generated by randomly choosing a case from the data set, it is a nonparametric method used to assess the significance level of partial least square estimates (Chin, 1998b).

The ten hypotheses were tested using the PLS approach. The significance of each hypothesized relationship included in the research model was examined based on the path coefficients $(\beta)$ and t-statistics of each hypothesized relationship. The positive or negative path coefficient of a relationship indicated whether an independent variable increases or decreases the magnitude of the dependent variable, respectively. Based on the significance of the hypothesized relationships, the relationship is significant at $p<0.05$ if a t-value is $>1.960$, whereas the relationship is significant at $\mathrm{p}<0.01$ if a t-value is $>2.575$.

Furthermore, Hair et al. (2011) proposed that the $\mathrm{R}^{2}$ values of $0.25,0.50$, and 0.75 in the structural model of PLS can be interpreted as weak, moderate, and substantial, respectively. This measurement refers to the extent in which the independent variables explain the dependent variable. Unlike the covariance-based structural equation modeling, PLS does not provide various methods to validate the models, such as $\chi^{2}$ and other related measures (Henseler \& Sarstedt, 2013). The criterion goodness of fit (GoF) for PLS was proposed by Tenenhaus, Vinzi, Chatelin, and Lauro (2005) as the geometric means of the average communality and the average $\mathrm{R}^{2}$. The communality is the average proportion of variance explained by the indicators for a specific variable, and it is an index indicating the measurement quality of each variable (Fornell \& Larcker, 1981; Tenenhaus et al., 2005). Furthermore, GoF was defined as small (0.35), medium (0.50), and large (0.61) (Latan \& Ghozali, 2012).

\section{Findings}

\subsection{Measurement model}

All the standard factor-loading values in the measurement model were larger than 0.5 and significant at $\mathrm{p}=0.01$. The composite reliabilities of constructs ranged from 0.87 to 0.97 , and the AVE's scope was from 0.62 to 0.85 . Thus, the above criteria for convergent validity were fulfilled (Table 2). To assess discriminant validity, the square root of the AVE should exceed the correlations between the construct and any other factor in the model (Chin, 1998b). All 
constructs in this study satisfied the requirement (Table 3).

\subsection{Structural model}

Table 4 lists the analysis results derived through the PLS structural model. In relation to policy support for inducement, H1, H7, and H9 were supported but $\mathrm{H} 3$ and $\mathrm{H} 5$ were not. This shows that the support of an individual for inducement policy measures can be explained by attitude $(\beta=0.36, p<0.01)$, past behaviour $(\beta=0.24, p<0.01)$, and perceived policy effectiveness $(\beta=0.21, p<0.01)$. External influences and perceived benefits were not statistically significant at $p=0.05$. The variables accounted for $57.3 \%$ of the variance in the policy support for inducement measures; thus, a moderate amount of variance can be explained by the proposed independent variables (Hair et al., 2011). This positive path coefficients $(\beta)$ means that the support of an individual for inducement policy measures is increased when the individual has more positive attitudes towards recycling, has increased past recycling behaviours, and perceives a high level of policy effectiveness.

In relation to another dependent variable defined in this study, namely, policy support for capacity-building measures, $\mathrm{H} 4$ and $\mathrm{H} 6$ were supported but H2, H8, and H10 were not. This shows that the support of an individual for capacity-building policy measures can be explained by external influences $(\beta=0.25, p<0.01)$ and perceived benefits $(\beta=0.19, p<$ $0.05)$. The other three independent variables, attitude, past behaviour, and perceived policy effectiveness were not statistically significant. These variables accounted for $19.8 \%$ of the variance in the policy support for capacity-building measures; thus, the structural model is comparatively weak (Hair et al., 2011). This result means that if an individual experiences positive external influences for recycling and perceives higher levels of recycling benefits, the individual tends to support capacity-building policy measures.

Using the criterion goodness of fit (GoF) for PLS as proposed by Tenenhaus et al. (2005), this study determined the GoF value of the model as 0.54 , which was a medium fit. Therefore, this result is acceptable.

\section{Discussion}

Three variables, namely, attitude, past behaviour, and perceived policy effectiveness were positively correlated with policy support for inducement. Thus, if an individual has a more positive attitude, past behaviour, and perceived policy effectiveness, he/she is more likely to support the government in imposing incentives or disincentives that can improve recycling rates. This finding is consistent with results of empirical studies in the areas of environmental 
psychology and behaviours (Daneshvary et al., 1998; Rauwald \& Moore, 2002).

Rather than the general environmental attitude used by Rauwald and Moore (2002), this study applied recycling attitudes as an independent variable, rather than the general environmental attitude of the NEP developed by Dunlap and Van Liere (1978). (Do Valle et al., 2005), Oom Do Valle et al. (2005), and Balderjahn (1988) argued that specific attitude would yield more accurate and consistent results on pro-environmental behaviour compared with general environmental attitude. Although external influences and perceived benefits were not statistically correlated with the support for inducement policy measures, these two variables are significant factors that positively impact the support for capacity building. This means that an individual is more likely to support the government's investment on recycling facilities, civil education, and waste management infrastructure, if he/she perceives high levels of recycling benefits and positive external influences from peers, media, and interest groups. These results are consistent with those of the study Tobler et al. (2012) and the conceptual idea by Kingdon (1995).

Notably, the support for the two categories of policy measures were statistically correlated with two different sets of independent variables. Inducements are commonly used to motivate or demotivate the behaviour of an individual. For example, waste charging is a disincentive for waste production, such that, individuals may produce less waste and recycle more to reduce the charges incurred. Furthermore, capacity building is future oriented and focuses on the society as a whole; thus, governments can invest on human, social, and physical capacities (Elmore, 1987). In the context of recycling, cultivating civil education and establishing recycling facilities are examples of capacity building. Therefore, the impacts of inducement are short term, whereas those of capacity building are long term.

Inducement involves changes in individual behavioral choices, similar to the effect of the structural strategies proposed by Steg and Vlek (2009), whereas capacity building develops the city as a whole. Attitude, past behaviour, and perceived policy effectiveness are factors related to the nature of individual belief, perception, and behaviour. This can account for the correlation of these variables with the support for inducement policy measures. Past behaviour is a significant factor that positively influences the support for inducement policy measure because an individual who had engaged in recycling and inducement policy measures (e.g., waste charging) will not perceive these to have a significant impact on him/ her.

External influences and perceived benefits are statistically and positively correlated with the support for capacity-building policy measures. These two constructs measure the perceived 
influence by peers, media, and pressure groups, as well as the perceived environmental benefits of recycling. Peer, media and pressures groups are more at a collective level compared with individual attitudes and beliefs. This result suggests that individual behaviours are influenced by significant others (e.g., peers and friends) and by the media and pressure groups. In addition, perceived environmental benefits are relatively long term and at a macro level. This explains why these two factors influence capacity-building support.

Policy makers can identify the key challenges and considerations for the design and implementation of recycling policies by using these findings. If the government imposes waste charges and plastic bag levy (i.e., inducements) to encourage waste reduction, attitude can be influenced by promotional program that implement a variety of attitude-change strategies (Schiffman, Kanuk, \& Wisenblit, 2010). For example, changing the motivational function through the following measures can alter attitudes:

- Stressing the importance to recycle

- Linking with an admired group or event to project a favorable image

Controlling past behaviour is a challenge. The government should emphasize timing, public participation, policy tool choice, and communication (Wan \& Shen, 2013) to improve the perceived effectiveness of public policy. Promotional programs that highlight the environmental benefits of recycling will gain policy support for investment on civil education and waste management facilities. Furthermore, the government can utilize marketing communication and public relation events to package participation in recycling activities as a social norm and trend. Feasible ways comprise linking with an admired group or event, celebrity endorsement, teaming up with interest groups, and promoting recycling in the media. These will similarly gain policy support for capacity building.

This study has identified limitations that should be addressed through future research. The obvious limitation is the relatively small sample. Moreover, the local policy measures on waste reduction and recycling can exhibit unique characteristics. Therefore, the findings may or may not be generalizable in other areas and contexts.

Further research should be conducted. Further, the model should be applied to different settings and different groups based on the following concerns:

- This study used street survey to cover a wide population. However, the sample was overrepresented by the youth group (ages below 30). The results should be verified using other age groups.

- This study considered perceived policy effectiveness measure as a single construct. Thus, the relation between the perceived effectiveness of each policy tool and support should be 
studied.

- Future studies should examine political affiliation, which was not addressed by the present study. The study of Tobler et al. (2012) on climate change showed that policy support is influenced by political affiliation.

\section{Conclusions}

This study identified the determinants of policy support in the context of recycling. Results indicate that the support for inducement policy measures is influenced by attitude, past behaviour, and perceived policy effectiveness, whereas support for capacity-building policy measures is influenced by external influences and perceived benefits. Previous studies that aimed to understand policy support on various environmental issues, such as climate change, establishment of national parks, and textile-curbside recycling have been conducted. However, no censual model that can explain the policy support for recycling is available.

This study addressed the gaps in literature. First, a comprehensive list of psychological determinants, namely attitude, external influences, perceived benefits, past behaviour and perceived policy effectiveness was incorporated in the empirical research model. Second, this study considered policy support as a complicated construct, which should be differentiated based on the policy tools implemented in this study (i.e., inducement and capacity building). The enhanced model can assist policy makers in gaining better understanding of the factors that affect recycling intention. The model can also assist in realizing that the support for different categories of policy measures are influenced by different factors, which may have been caused by the short-term versus long-term oriented natures and individualized versus city-wide concerns.

In order to gain public support for inducement policy measures, public authorities should focus on attitude and perceived policy effectiveness. To enhance people's attitudes towards recycling, Tonglet, Phillips, and Read (2004) suggested 'good citizen approach' and 'feel good factor' (p.211), these refer to highlight in the promotional campaigns that recycling is a responsible behaviour of citizens and personally rewarding. In addition, people's perception of policy effectiveness can be enhanced through informing the public about the efforts and achievements of the public authorities in addressing the waste problems (Wan et al., 2014). Conversely, support for capacity-building policy measures requires an alternative promotional approach that should focus on external influences and perceived benefits. Therefore, the promotional message can highlight recycling as a social trend by indicating the number of people participated or by illustrating celebrities' participation in recycling activities. Furthermore, public authorities can also emphasize how recycling can help in the 
conservation of natural resources and the protection of environment. 


\section{References}

Abrahamse, W., \& Steg, L. (2013). Social influence approaches to encourage resource conservation: A meta-analysis. Global environmental change, 23(6), 1773-1785.

Ajzen, I. (1991). The theory of planned behavior. Organizational behavior and human decision processes, 50(2), 179-211.

Balderjahn, I. (1988). Personality variables and environmental attitudes as predictors of ecologically responsible consumption patterns. Journal of business Research, 17(1), 51-56.

Bamberg, S., \& Möser, G. (2007). Twenty years after Hines, Hungerford, and Tomera: A new meta-analysis of psycho-social determinants of pro-environmental behaviour. Journal of Environmental Psychology, 27(1), 14-25.

Barr, S. (2007). Factors Influencing Environmental Attitudes and Behaviors A UK Case Study of Household Waste Management. Environment and Behavior, 39(4), 435-473.

Barr, S., Gilg, A. W., \& Ford, N. J. (2001). Differences between household waste reduction, reuse and recycling behaviour: a study of reported behaviours, intentions and explanatory variables. Environmental \& Waste Management, 4(2), 69-82.

Bator, R. J., Bryan, A. D., \& Schultz, P. W. (2010). Who gives a hoot? Intercept surveys of litterers and disposers. Environment and Behavior, 0013916509356884.

Belton, V., Crowe, D. V., Matthews, R., \& Scott, S. (1994). A survey of public attitudes to recycling in Glasgow (UK). Waste management \& research, 12(4), 351-367.

Björklund, A., \& Finnveden, G. (2005). Recycling revisited-life cycle comparisons of global warming impact and total energy use of waste management strategies. Resources, Conservation and Recycling, 44(4), 309-317.

Boldero, J. (1995). The prediction of household recycling of newspapers: The role of attitudes, intentions, and situational factors1. Journal of Applied Social Psychology, 25(5), 440-462.

Campbell, D. T., \& Fiske, D. W. (1959). Convergent and discriminant validation by the multitrait-multimethod matrix. Psychological Bulletin, 56(2), 81.

Carrus, G., Passafaro, P., \& Bonnes, M. (2008). Emotions, habits and rational choices in ecological behaviours: The case of recycling and use of public transportation. Journal of Environmental Psychology, 28(1), 51-62.

Chan, E., \& Chan, J. (2007). The first ten years of the HKSAR: Civil society comes of age. Asia Pacific Journal of Public Administration, 29(1), 77-99.

Chan, K. (1998). Mass communication and pro-environmental behaviour: waste recycling in Hong Kong. Journal of Environmental Management, 52(4), 317-325.

Chan, R. Y. (2001). Determinants of Chinese consumers' green purchase behavior. Psychology \& Marketing, 18(4), 389-413. 
Chan, W. (2007). Urban Activism for effective governance a new civil society campaign in the HKSAR: Hong Kong Policy Research Institute.

Chen, M.-F., \& Tung, P.-J. (2009). The moderating effect of perceived lack of facilities on consumers' recycling intentions. Environment and Behavior.

Cheung, A. (2007). Policy capacity in post-1997 Hong Kong: constrained institutions facing a crowding and differentiated polity. Asia Pacific Journal of Public Administration, 29(1), 51-75.

Cheung, S. F., Chan, D. K.-S., \& Wong, Z. S.-Y. (1999). Reexamining the theory of planned behavior in understanding wastepaper recycling. Environment and Behavior, 31(5), 587-612.

Chin, W. W. (1998a). Commentary: Issues and opinion on structural equation modeling: JSTOR.

Chin, W. W. (1998b). The partial least squares approach to structural equation modeling. Modern methods for business research, 295(2), 295-336.

Cialdini, R. B., \& Goldstein, N. J. (2004). Social influence: Compliance and conformity. Annual review of psychology, 55, 591-621.

Cialdini, R. B., \& Trost, M. R. (1998). Social influence: Social norms, conformity and compliance. In L. Gardner, G. Daniel, \& S. T. Fiske (Eds.), The Handbook of Social Psychology: Oxford University Press.

Courtenay-Hall, P., \& Rogers, L. (2002). Gaps in mind: Problems in environmental knowledge-behaviour modelling research. Environmental education research, 8(3), 283-297.

Daneshvary, N., Daneshvary, R., \& Schwer, R. K. (1998). Solid-waste recycling behavior and support for curbside textile recycling. Environment and Behavior, 30(2), 144-161.

Davies, J., Foxall, G. R., \& Pallister, J. (2002). Beyond the intention-behaviour mythology an integrated model of recycling. Marketing theory, 2(1), 29-113.

Do Valle, P. O., Rebelo, E., Reis, E., \& Menezes, J. (2005). Combining behavioral theories to predict recycling involvement. Environment and Behavior, 37(3), 364-396.

Dolnicar, S., \& Grün, B. (2009). Environmentally Friendly Behavior Can Heterogeneity Among Individuals and Contexts/Environments Be Harvested for Improved Sustainable Management? Environment and Behavior, 41(5), 693-714.

Dunlap, R. E., \& Van Liere, K. D. (1978). The "new environmental paradigm". The journal of environmental education, 9(4), 10-19.

Ebreo, A., \& Vining, J. (2001). How similar are recycling and waste reduction? Future orientation and reasons for reducing waste as predictors of self-reported behavior. Environment and Behavior, 33(3), 424-448.

Elmore, R. F. (1987). Instruments and strategy in public policy. Review of Policy Research, $7(1), 174-186$. 
Environmental Bureau. (2013). Hong Kong: Blueprint for Sustainable Use of Resources 2013-2022. Hong Kong: The Government of the Hong Kong Special Administrative Region Retrieved from http://www.epd.gov.hk/epd/msw/index.html.

Environmental Protection Department. (2005). A policy framework for the management of municipal solid waste, 2005 - 2014. Hong Kong: The Government of the Hong Kong Special Administrative Region Retrieved from http://www.epd.gov.hk/epd/msw/index.html.

Environmental Protection Department. (2010). An overview on challenges for waste reduction and management in Hong Kong. Hong Kong: The Government of the Hong Kong Special Administration Region Retrieved from An overview on challenges for waste reduction and management in Hong Kong.

Field, A., Miles, J., \& Field, Z. (2012). Discovering Statistics Using SPSS: SAGE Publications.

Fielding, K. S., McDonald, R., \& Louis, W. R. (2008). Theory of planned behaviour, identity and intentions to engage in environmental activism. Journal of Environmental Psychology, 28(4), 318-326.

Fishbein, M., \& Ajzen, I. (1975). Belief, attitude, intention, and behavior: an introduction to theory and research: Addison-Wesley Pub. Co.

Fornell, C., \& Larcker, D. F. (1981). Evaluating structural equation models with unobservable variables and measurement error. Journal of marketing research, 39-50.

Fransson, N., \& Gärling, T. (1999). Environmental concern: Conceptual definitions, measurement methods, and research findings. Journal of Environmental Psychology, 19(4), 369-382.

González-Torre, P. L., \& Adenso-Díaz, B. (2005). Influence of distance on the motivation and frequency of household recycling. Waste Management, 25(1), 15-23.

Hair, J. F., Ringle, C. M., \& Sarstedt, M. (2011). PLS-SEM: Indeed a silver bullet. The Journal of Marketing Theory and Practice, 19(2), 139-152.

Hawcroft, L. J., \& Milfont, T. L. (2010). The use (and abuse) of the new environmental paradigm scale over the last 30 years: A meta-analysis. Journal of Environmental Psychology, 30(2), 143-158.

Heath, Y., \& Gifford, R. (2002). Extending the theory of planned behavior: predicting the use of public transportation. Journal of Applied Social Psychology, 32(10), 2154-2189.

Henry, R. K., Yongsheng, Z., \& Jun, D. (2006). Municipal solid waste management challenges in developing countries-Kenyan case study. Waste Management, 26(1), 92-100.

Henseler, J., Ringle, C. M., \& Sinkovics, R. R. (2009). The use of Partial Least Squares Path Modeling in International Marketing. Advances in International Marketing, 20, 277-319. 
Henseler, J., \& Sarstedt, M. (2013). Goodness-of-fit indices for partial least squares path modeling. Computational Statistics, 28(2), 565-580.

Hui, P. (2010, 24 Feb). Hong Kong's younger generation pushing for change. The Telegraph.

Jakobsson, C., Fujii, S., \& Gärling, T. (2000). Determinants of private car users' acceptance of road pricing. Transport Policy, 7(2), 153-158.

Jöreskog, K. G., \& Sörbom, D. (1989). LISREL 7: A guide to the program and applications: Spss.

Jöreskog, K. G., \& Wold, H. (1982). The ML and PLS techniques for modeling with latent variables: historical and comparative aspects. In K. G. Jöreskog \& H. Wold (Eds.), Systems Under Indirect Observation, Part 1 (pp. 263-270).

Kingdon, J. W. (1995). Agendas, Alternatives, and Public Policies: HarperCollins College Publishers.

Knussen, C., Yule, F., MacKenzie, J., \& Wells, M. (2004). An analysis of intentions to recycle household waste: The roles of past behaviour, perceived habit, and perceived lack of facilities. Journal of Environmental Psychology, 24(2), 237-246.

Kollmuss, A., \& Agyeman, J. (2002). Mind the gap: why do people act environmentally and what are the barriers to pro-environmental behavior? Environmental education research, 8(3), 239-260.

Latan, H., \& Ghozali, I. (2012). Partial least Squares: Concept and application path modeling using program XLSTAT-PLS for empirical research, BP UNDIP.

Lu, I. R., Kwan, E., Thomas, D. R., \& Cedzynski, M. (2011). Two new methods for estimating structural equation models: An illustration and a comparison with two established methods. International Journal of research in Marketing, 28(3), 258-268.

Lubell, M. (2003). Collaborative institutions, belief-systems, and perceived policy effectiveness. Political Research Quarterly, 56(3), 309-323.

McCombs, M. E., \& Shaw, D. L. (1972). The agenda-setting function of mass media. Public opinion quarterly, 36(2), 176-187.

McKenzie-Mohr, D., Nemiroff, L. S., Beers, L., \& Desmarais, S. (1995). Determinants of responsible environmental behavior. Journal of social issues, 51(4), 139-156.

Miller, G. A. (1956). The magical number seven, plus or minus two: some limits on our capacity for processing information. Psychological review, 63(2), 81.

Monroe, M. C. (2003). Two avenues for encouraging conservation behaviors. Human Ecology Review, 10(2), 113-125.

Mont, O., \& Plepys, A. (2008). Sustainable consumption progress: should we be proud or alarmed? Journal of Cleaner Production, 16(4), 531-537.

Ouellette, J. A., \& Wood, W. (1998). Habit and intention in everyday life: the multiple processes by which past behavior predicts future behavior. Psychological Bulletin, 124(1), 54. 
Phillips, T. (2014, 13 December). Hong Kong's Umbrella Movement spawns new generation of protester - but can they even win? The Telegraph.

Poortinga, W., Steg, L., \& Vlek, C. (2004). Values, environmental concern, and environmental behavior a study into household energy use. Environment and Behavior, 36(1), 70-93.

Rauwald, K. S., \& Moore, C. F. (2002). Environmental attitudes as predictors of policy support across three countries. Environment and Behavior, 34(6), 709-739.

Reinartz, W., Haenlein, M., \& Henseler, J. (2009). An empirical comparison of the efficacy of covariance-based and variance-based SEM. International Journal of research in Marketing, 26(4), 332-344.

Ringle, C. M., Wende, S., \& Will, S. (2005). SmartPLS 2.0 (M3) Beta, Hamburg.

Schiffman, L. G., Kanuk, L. L., \& Wisenblit, J. (2010). Consumer Behavior: Pearson Prentice Hall.

Schneider, A., \& Ingram, H. (1990). Behavioral assumptions of policy tools. The Journal of Politics, 52(02), 510-529.

Schultz, P. W., \& Oskamp, S. (1996). Effort as a moderator of the attitude-behavior relationship: General environmental concern and recycling. Social psychology quarterly, 375-383.

Sidique, S. F., Lupi, F., \& Joshi, S. V. (2010). The effects of behavior and attitudes on drop-off recycling activities. Resources, Conservation and Recycling, 54(3), 163-170.

Sin, D., \& Mok, D. (2010, 17 January). Scholar of generation gaps looks past the post-80s. South China Morning Post. Retrieved from http://www.scmp.com/article/703936/scholar-generation-gaps-looks-past-post-80s

Steg, L., Dreijerink, L., \& Abrahamse, W. (2005). Factors influencing the acceptability of energy policies: A test of VBN theory. Journal of Environmental Psychology, 25(4), 415-425.

Steg, L., \& Vlek, C. (2009). Encouraging pro-environmental behaviour: An integrative review and research agenda. Journal of Environmental Psychology, 29(3), 309-317.

Stern, P. C. (1992). Psychological dimensions of global environmental change. Annual review of psychology, 43(1), 269-302.

Stern, P. C. (2000). New environmental theories: toward a coherent theory of environmentally significant behavior. Journal of social issues, 56(3), 407-424.

Tang, B.-s., Wong, S.-w., \& Lee, A. K.-w. (2007). Green belt in a compact city: A zone for conservation or transition? Landscape and Urban planning, 79(3), 358-373.

Tenenhaus, M., Vinzi, V. E., Chatelin, Y.-M., \& Lauro, C. (2005). PLS path modeling. Computational statistics \& data analysis, 48(1), 159-205.

Thøgersen, J., \& Ölander, F. (2003). Spillover of environment-friendly consumer behaviour. Journal of Environmental Psychology, 23(3), 225-236. 
Tobler, C., Visschers, V. H., \& Siegrist, M. (2012). Addressing climate change: Determinants of consumers' willingness to act and to support policy measures. Journal of Environmental Psychology, 32(3), 197-207.

Tonglet, M., Phillips, P. S., \& Bates, M. P. (2004). Determining the drivers for householder pro-environmental behaviour: waste minimisation compared to recycling. Resources, Conservation and Recycling, 42(1), 27-48.

Tonglet, M., Phillips, P. S., \& Read, A. D. (2004). Using the Theory of Planned Behaviour to investigate the determinants of recycling behaviour: a case study from Brixworth, UK. Resources, Conservation and Recycling, 41(3), 191-214.

Vedung, E., Bemelmans-Videc, M., \& Rist, R. (1998). Policy instruments: typologies and theories. Carrots, sticks, and sermons: Policy instruments and their evaluation, 21-58.

Vermeir, I., \& Verbeke, W. (2006). Sustainable food consumption: Exploring the consumer "attitude-behavioral intention" gap. Journal of Agricultural and Environmental Ethics, 19(2), 169-194.

Vlek, C., \& Steg, L. (2007). Human Behavior and Environmental Sustainability: Problems, Driving Forces, and Research Topics. Journal of social issues, 63(1), 1-19.

Wan, C., \& Shen, G. Q. (2013). Perceived policy effectiveness and recycling behaviour: The missing link. Waste Management, 33(4), 783-784.

Wan, C., Shen, G. Q., \& Yu, A. (2014). The role of perceived effectiveness of policy measures in predicting recycling behaviour in Hong Kong. Resources Conservation and Recycling, 83, 141-151. 
Table 1 Respondent Profile

\begin{tabular}{|c|c|c|}
\hline Demographic Variable & $\mathbf{N}$ & Percentage \\
\hline \multicolumn{3}{|l|}{ Gender } \\
\hline Female & 131 & $53.25 \%$ \\
\hline Male & 115 & $46.75 \%$ \\
\hline \multicolumn{3}{|l|}{ Age } \\
\hline Under 20 & 9 & $3.66 \%$ \\
\hline $20-24$ & 83 & $33.74 \%$ \\
\hline $25-29$ & 50 & $20.33 \%$ \\
\hline $30-34$ & 48 & $19.51 \%$ \\
\hline $35-39$ & 10 & $4.07 \%$ \\
\hline $40-44$ & 12 & $4.88 \%$ \\
\hline $45-49$ & 17 & $6.91 \%$ \\
\hline 50 or above & 17 & $6.91 \%$ \\
\hline \multicolumn{3}{|l|}{ Education Level } \\
\hline Primary & 22 & $8.94 \%$ \\
\hline Lower Secondary & 9 & $3.66 \%$ \\
\hline Upper Secondary & 71 & $28.86 \%$ \\
\hline Sub-degree & 44 & $17.89 \%$ \\
\hline Bachelor's Degree & 89 & $36.18 \%$ \\
\hline Master's Degree or above & 11 & $4.47 \%$ \\
\hline \multicolumn{3}{|l|}{ Monthly Income (HK\$) } \\
\hline Below 9999 & 95 & $38.62 \%$ \\
\hline $10,000-19,999$ & 92 & $37.40 \%$ \\
\hline $20,000-29,999$ & 31 & $12.60 \%$ \\
\hline $30,000-39,999$ & 20 & $8.13 \%$ \\
\hline $40,000-49,999$ & 4 & $1.63 \%$ \\
\hline Above 50,000 & 4 & $1.63 \%$ \\
\hline
\end{tabular}


Table 2 The Measurement Model

\begin{tabular}{|c|c|c|c|c|}
\hline Constructs & Indicators & $\begin{array}{c}\text { Factor } \\
\text { Loadings }\end{array}$ & $\begin{array}{c}\text { Average } \\
\text { Variance } \\
\text { Extracted } \\
\text { (AVE) }\end{array}$ & $\begin{array}{c}\text { Composite } \\
\text { Reliability (CR) }\end{array}$ \\
\hline $\begin{array}{l}\text { Attitude } \\
\text { (ATTD) }\end{array}$ & $\begin{array}{l}\text { ATTD1 } \\
\text { ATTD2 } \\
\text { ATTD3 } \\
\text { ATTD4 } \\
\text { ATTD5 } \\
\text { ATTD6 }\end{array}$ & $\begin{array}{l}0.908 \\
0.944 \\
0.955 \\
0.881 \\
0.948 \\
0.886 \\
\end{array}$ & 0.85 & 0.97 \\
\hline External Influences (EI) & $\begin{array}{l}\text { EI1 } \\
\text { EI2 } \\
\text { EI3 } \\
\text { EI4 } \\
\text { EI5 } \\
\end{array}$ & $\begin{array}{l}0.751 \\
0.597 \\
0.754 \\
0.906 \\
0.890 \\
\end{array}$ & 0.62 & 0.89 \\
\hline Perceived Benefits (PB) & $\begin{array}{l}\text { PB1 } \\
\text { PB2 } \\
\text { PB3 } \\
\text { PB4 }\end{array}$ & $\begin{array}{l}0.853 \\
0.891 \\
0.821 \\
0.897 \\
\end{array}$ & 0.75 & 0.92 \\
\hline Past Behaviour (PBEV) & $\begin{array}{l}\text { PBEV1 } \\
\text { PBEV2 } \\
\text { PBEV3 }\end{array}$ & $\begin{array}{l}0.955 \\
0.957 \\
0.856 \\
\end{array}$ & 0.85 & 0.95 \\
\hline $\begin{array}{l}\text { Perceived Policy Effectiveness } \\
\text { (PPE) }\end{array}$ & $\begin{array}{l}\text { PPE1 } \\
\text { PPE2 } \\
\text { PPE3 } \\
\text { PPE4 } \\
\text { PPE5 } \\
\text { PPE6 } \\
\text { PPE7 } \\
\text { PPE8 }\end{array}$ & $\begin{array}{l}0.815 \\
0.782 \\
0.846 \\
0.766 \\
0.848 \\
0.772 \\
0.888 \\
0.879 \\
\end{array}$ & 0.68 & 0.94 \\
\hline $\begin{array}{l}\text { Policy Support - Inducement } \\
\text { (PS-I) }\end{array}$ & $\begin{array}{l}\text { PS-I1 } \\
\text { PS-I2 } \\
\text { PS-I3 } \\
\end{array}$ & $\begin{array}{l}0.875 \\
0.893 \\
0.704 \\
\end{array}$ & 0.69 & 0.87 \\
\hline $\begin{array}{l}\text { Policy Support - } \\
\text { Capacity-building (PS-C) }\end{array}$ & $\begin{array}{l}\text { PS-C1 } \\
\text { PS-C2 }\end{array}$ & $\begin{array}{l}0.882 \\
0.905\end{array}$ & 0.80 & 0.89 \\
\hline
\end{tabular}


Table 3 Correlations among Constructs

\begin{tabular}{|c|c|c|c|c|c|c|c|}
\hline Constructs & ATTD & EI & PB & PBEV & PPE & PS-I & PS-C \\
\hline Attitude (ATTD) & 0.92 & & & & & & \\
\hline External Influences (EI) & 0.58 & 0.79 & & & & & \\
\hline Perceived Benefits (PB) & 0.81 & 0.55 & 0.87 & & & & \\
\hline Past Behaviour (PBEV) & 0.65 & 0.58 & 0.60 & 0.92 & & & \\
\hline Perceived Policy Effectiveness (PPE) & 0.62 & 0.49 & 0.60 & 0.61 & $\mathbf{0 . 8 3}$ & & \\
\hline Policy Support - Inducement (PS-I) & 0.70 & 0.47 & 0.63 & 0.64 & 0.62 & $\mathbf{0 . 8 3}$ & \\
\hline Policy Support - Capacity-building (PS-C) & 0.35 & 0.40 & 0.38 & 0.31 & 0.32 & 0.47 & 0.89 \\
\hline
\end{tabular}

Note: Figures in bold are the square roots of the average variance extracted (AVE). 
Table 4 Testing Results

\begin{tabular}{|c|c|c|c|c|c|c|c|c|}
\hline \multirow[b]{2}{*}{ Constructs } & \multicolumn{4}{|c|}{$\begin{array}{c}\text { Dependent Variable: } \\
\text { Policy Support - Inducement (PS-I) }\end{array}$} & \multicolumn{4}{|c|}{$\begin{array}{c}\text { Dependent Variable: } \\
\text { Policy Support - Capacity-building } \\
\text { (PS-C) }\end{array}$} \\
\hline & $\beta$ & t-value & $\mathrm{p}$-value & Sig. & $\beta$ & t-value & $\mathrm{p}$-value & Sig. \\
\hline Attitude (ATTD) & 0.357 & 4.583 & 0.000005 & $* *$ & 0.006 & 0.054 & 0.956946 & \\
\hline External Influences (EI) & -0.026 & 0.431 & 0.666561 & & 0.247 & 2.997 & 0.002794 & $* *$ \\
\hline Perceived Benefits (PB) & 0.085 & 1.029 & 0.303729 & & 0.192 & 1.982 & 0.047753 & $*$ \\
\hline Past Behaviour (PBEV) & 0.240 & 3.971 & 0.000077 & $* *$ & 0.001 & 0.016 & 0.987238 & \\
\hline $\begin{array}{l}\text { Perceived Policy } \\
\text { Effectiveness (PPE) }\end{array}$ & 0.208 & 3.268 & 0.001120 & $* *$ & 0.077 & 0.824 & 0.410136 & \\
\hline $\mathrm{R}^{2}$ & \multicolumn{4}{|c|}{0.573} & \multicolumn{4}{|c|}{0.198} \\
\hline
\end{tabular}

Note: if a p-value is smaller than 0.05 , the null hypothesis is rejected and this indicates a significant relationship between the independent and dependent variables.

$* p<0.05, * * p<0.01$ 


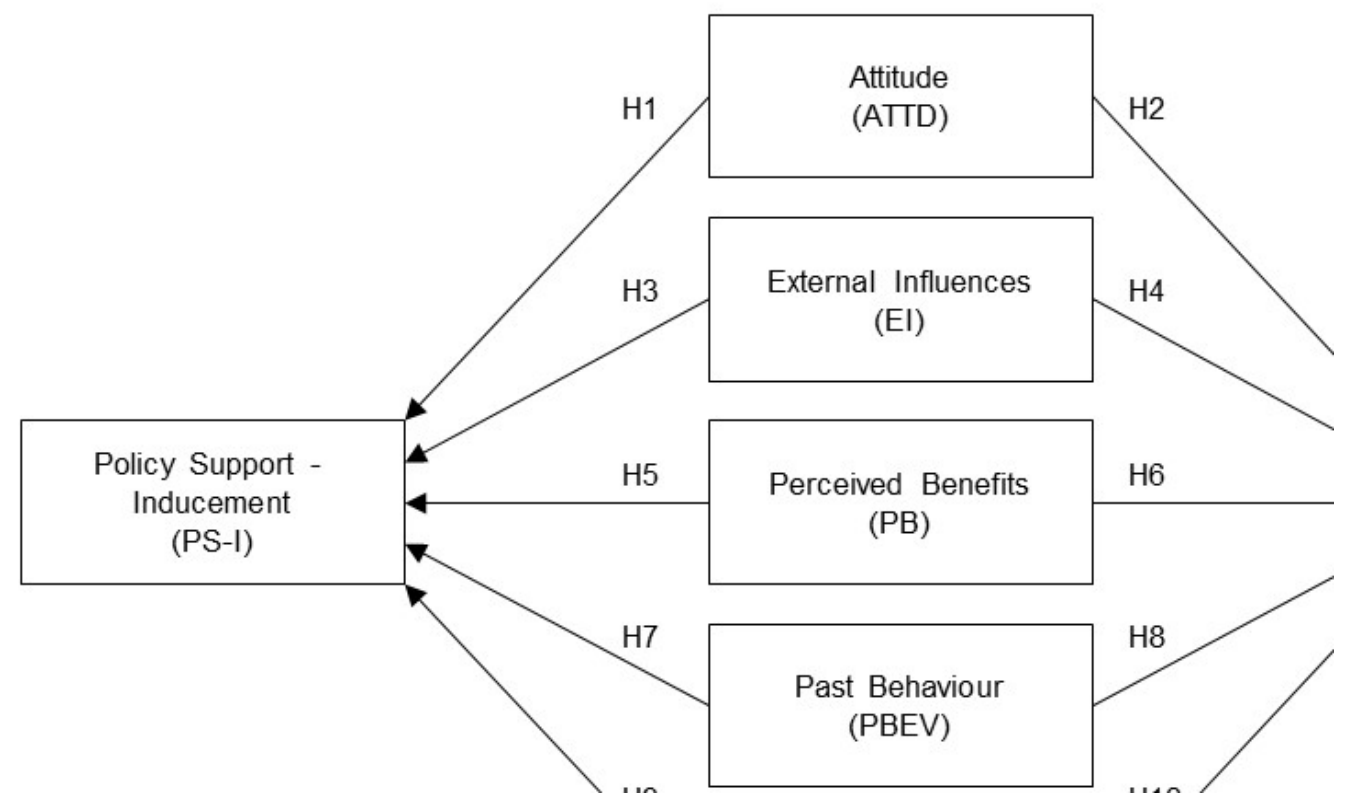

Figure 1 The conceptual framework 


\section{Appendix A}

\begin{tabular}{|c|c|c|}
\hline Constructs / Variables & & Indicators / Questionnaire Items \\
\hline \multirow{6}{*}{$\begin{array}{l}\text { Attitude } \\
\text { (ATTD) }\end{array}$} & ATTD1 & Recycling is good. \\
\hline & ATTD2 & Recycling is useful. \\
\hline & ATTD3 & Recycling is rewarding. \\
\hline & ATTD4 & Recycling is responsible. \\
\hline & ATTD5 & Recycling is sensible. \\
\hline & ATTD6 & Recycling is hygienic. \\
\hline \multirow[t]{5}{*}{ External Influences (EI) } & EI1 & My friends expect me to recycle household materials. \\
\hline & EI2 & My family expects me to recycle household materials. \\
\hline & EI3 & $\begin{array}{l}\text { My co-workers or schoolmates expect me to recycle household } \\
\text { materials. }\end{array}$ \\
\hline & EI4 & Media influences me to recycle recyclables. \\
\hline & EI5 & Environmental groups influence me to recycle recyclables. \\
\hline \multirow[t]{4}{*}{ Perceived Benefits (PB) } & PB1 & Recycling reduces wasteful use of landfills. \\
\hline & PB2 & Recycling saves energy. \\
\hline & PB3 & Recycling saves money. \\
\hline & PB4 & Recycling creates a better environment for future generations. \\
\hline \multirow[t]{3}{*}{ Past Behaviour (PBEV) } & PBEV1 & I have recycled my recyclables in the past 4 weeks. \\
\hline & PBEV2 & $\begin{array}{l}\text { I have been recycling my recyclables regularly in the past } 4 \\
\text { weeks. }\end{array}$ \\
\hline & PBEV3 & I have recycling behaviour at home. \\
\hline \multirow{8}{*}{$\begin{array}{l}\text { Perceived Policy } \\
\text { Effectiveness } \\
\text { (PPE) }\end{array}$} & PPE1 & $\begin{array}{l}\text { The waste separation bins provided by the Government are } \\
\text { sufficient to facilitate recycling. }\end{array}$ \\
\hline & PPE2 & $\begin{array}{l}\text { The environmental programmes organized by the Government } \\
\text { effectively arouse environmental awareness of the general } \\
\text { public. }\end{array}$ \\
\hline & PPE3 & The Government provides clear guidelines on recycling. \\
\hline & PPE4 & $\begin{array}{l}\text { The Government's promotion helps citizens understand the } \\
\text { importance of recycling. }\end{array}$ \\
\hline & PPE5 & $\begin{array}{l}\text { The Government's promotion clearly explains the benefits of } \\
\text { recycling. }\end{array}$ \\
\hline & PPE6 & $\begin{array}{l}\text { The Government promotes clearly recycling as positive symbols, } \\
\text { labels, images and events. }\end{array}$ \\
\hline & PPE7 & The Government's policy encourages me to recycle. \\
\hline & PPE8 & The Government's policy facilitates me to recycle. \\
\hline \multirow[t]{3}{*}{$\begin{array}{l}\text { Policy Support - } \\
\text { Inducement (PS-I) }\end{array}$} & PS-I1 & $\begin{array}{l}\text { I support extending the plastic bay levy to all retail stores in Hong } \\
\text { Kong. }\end{array}$ \\
\hline & PS-I2 & I support the introduction of municipal solid waste charging. \\
\hline & PS-I3 & $\begin{array}{l}\text { I support the charging scheme on construction waste (e.g. surplus } \\
\text { materials from renovation). }\end{array}$ \\
\hline Policy Support - & PS-C1 & I support the fund in enhancing publicity and public education. \\
\hline Capacity-building (PS-C) & PS-C2 & $\begin{array}{l}\text { I support the development of an EcoPark for the local recycling } \\
\text { industry. }\end{array}$ \\
\hline
\end{tabular}

